\title{
Degradation of hyaluronate by Streptococcus intermedius strain UNS 35
}

\author{
K. A. HOMER, M. C. GROOTVELD*, J. HAWKES $\dagger$, D. P. NAUGHTON* and D. BEIGHTON \\ Oral Microbiology, Royal College of Surgeons, Department of Dental Sciences, King's College School of Medicine \\ and Dentistry, Faculty of Clinical Dentistry, Caldecot Road, Denmark Hill, London SE5 9RW, * Inflammation \\ Research Group, The London Hospital Medical College, 25-29 Ashfield Street, London E1 2AD and † Department of \\ Chemistry, King's College (Strand Campus), University of London, The Strand, London WC2R 2LS
}

\begin{abstract}
Summary. Streptococcus intermedius strain UNS 35, a brain abscess isolate, produced extracellular hyaluronidase when grown in brain heart infusion broth. Chemical assays with this enzyme indicated that hyaluronate depolymerisation resulted in the formation of carbohydrate moieties with $\mathrm{N}$-acetylglucosamine at the reducing terminal and containing an unsaturated carbon-carbon double bond. The nature of the products of this hyaluronidase were investigated further by high-field ( $400 \mathrm{MHz})$ proton $\left({ }^{1} \mathrm{H}\right)$ NMR spectroscopy. Treatment of hyaluronate with the enzyme resulted in a series of new, sharp resonances in spectra (acetamido methyl group singlets located at 2.03 and $2.07 \mathrm{ppm}$, sugar ring proton multiplets in the $3.5-4.2 \mathrm{ppm}$ chemical shift range, and doublets at 5.16 and $5.87 \mathrm{ppm}$ ) characteristic of low- $\mathrm{M}_{\mathrm{r}}$ oligosaccharide species, predominantly those containing glucuronosyl residues with $\Delta 4,5$-carbon-carbon double bonds. Comparison of spectra acquired from hyaluronidasetreated samples with that of an authentic sample of 4-deoxy-L-threo-hex-4-enopyranosyluronic-acid-N-acetylglucosamine ( $\triangle \mathrm{UA}$ GlcNAc) indicated that this disaccharide was a major product arising from the actions of this enzyme. When used in minimal media, hyaluronate supported growth of $S$. intermedius, with lactate as the major metabolic endproduct.
\end{abstract}

\section{Introduction}

Hyaluronic acid is a linear polysaccharide composed of repeating disaccharide units containing glucuronic acid and $\mathrm{N}$-acetylglucosamine. ${ }^{1}$ It binds to proteoglycans and has an important role in the integrity and organisation of the extracellular matrix ${ }^{1,2}$ and is therefore important in the maintenance of form and the spatial arrangements of tissue components. The ability to elaborate enzymes that depolymerise hyaluronic acid is a principal virulence determinant for several bacterial pathogens, including Streptococcus pyogenes and Peptostreptococcus spp $^{3-5}$ The importance of this enzyme in the pathogenic process is a function of its ability to destroy host tissue and to act as a "spreading" factor, facilitating bacterial infiltration at the infection site.

$S$. intermedius, formerly part of the clinically important " $S$. milleri group", also produces a potent hyaluronidase $e^{6}$ and is of special interest because of its strong association with the formation of deep-seated, purulent abscesses of the liver and brain. ${ }^{7}$ There have been few investigations into the structure of the products arising from the actions of bacterial hyaluronidases, and the majority of these have involved labour-intensive, time-consuming laboratory methods, including prior purification of the enzyme to homogeneity., ${ }^{5,9}$ These studies indicated that the degradation products of bacterial hyaluronidases consist of linear oligosaccharides (primarily the disaccharide) with $\Delta 4,5$-unsaturated bonds at the glucuronosyl residue such as 4-deoxy-L-threo-hex-4enopyranosyluronic-acid-N-acetylglucosamine ( $\triangle \mathrm{UA}$ GlcNAc)..$^{5,8-10}$

In this investigation the degradation of hyaluronic acid by $S$. intermedius hyaluronidase was studied in chemical assays in conjunction with high resolution proton $\left({ }^{1} \mathrm{H}\right)$ NMR spectroscopy to ascertain the precise molecular nature of the oligosaccharides derived from the depolymerisation of hyaluronate. $\left({ }^{1} \mathrm{H}\right)$ NMR spectroscopy involves only minimal sample preparation before analysis. High resolution $\left({ }^{1} \mathrm{H}\right)$ NMR investigations of human and animal biofluids, e.g. blood plasma, ${ }^{11,12}$ knee joint synovial fluid ${ }^{13}$ and 
cell culture media, ${ }^{14}$ have provided much useful biochemical and clinical information. Moreover, the multicomponent analytical ability of high-field NMR analysis offers many advantages over alternative methods since chemical shifts, coupling patterns and coupling constants of resonances detectable in spectra of such samples offer much valuable information about the structures of biomolecules present. The broad overlapping resonances which arise from macromolecules present in untreated samples are routinely suppressed by the application of spin-echo pulse sequences ${ }^{15.16}$ resulting in spectra that contain many well resolved, sharp signals attributable to various low- $\mathrm{M}_{\mathrm{r}}$ metabolites.

In addition to investigating the structure of the products of the $S$. intermedius hyaluronidase, depolymerisation of hyaluronate as a pre-requisite for growth and the low- $\mathrm{M}_{\mathrm{r}}$ oligosaccharides to support growth in vitro were examined.

\section{Materials and methods}

\section{Growth of bacteria and preparation of crude hyaluronidase}

S. intermedius strain UNS35 was maintained by routine subculture on Fastidious Anaerobe Agar (Lab M, Salford, Lancs) supplemented with horse blood $5 \%$. Cultures were incubated for $48 \mathrm{~h}$ at $37^{\circ} \mathrm{C}$ in an anaerobic cabinet (Don Whitely Scientific, Shipley, W. Yorkshire). Single colonies were removed into 20$\mathrm{ml}$ volumes of Brain Heart Infusion Broth (BHI; Oxoid) and incubated anaerobically until early stationary phase. Cells were removed by centrifugation (13000 rpm, $10 \mathrm{~min}$ at ambient temperature) and culture supernates were used as the source of bacterial hyaluronidase.

\section{Assay of bacterial hyaluronidase activity}

The $\mathrm{pH}$ optimum of the crude $S$. intermedius hyaluronidase was determined in citric acid-trisodium citrate buffer ( $\mathrm{pH} 3 \cdot 0-6 \cdot 0)$ and $\mathrm{NaH}_{2} \mathrm{PO}_{4}-\mathrm{Na}_{2} \mathrm{HPO}_{4}$ (pH 6.0-8.0). Hyaluronic acid with an estimated $\mathrm{M}_{\mathrm{r}}$ of 60-100 kDa (sodium salt, derived from bovine trachea) was purchased from Sigma. Assays were set up in microfuge tubes and contained $35 \mu \mathrm{l}$ of $0.2 \mathrm{M}$ buffer; $20 \mu \mathrm{l}$ of hyaluronate $1 \mathrm{mg} / \mathrm{ml}$ in distilled water and an appropriate amount of the crude enzyme in a total volume of $100 \mu \mathrm{l}$. Assays were incubated at $37^{\circ} \mathrm{C}$ and 20- $\mu$ l samples were removed at intervals; residual undegraded hyaluronate was determined with the Stains-all dye-binding assay as described below. Control assays contained no hyaluronidase.

Large-scale hyaluronidase assays combined $3.5 \mathrm{ml}$ of $0.2 \mathrm{M} \mathrm{NaH} \mathrm{PO}_{4}-\mathrm{Na}_{2} \mathrm{HPO}_{4}$ buffer, pH $6.5,5 \mathrm{ml}$ of hyaluronate $4 \mathrm{mg} / \mathrm{ml}$ in distilled water and crude enzyme in a total volume of $10 \mathrm{ml}$. Assay mixtures, along with the appropriate controls, were incubated at $37^{\circ} \mathrm{C}$ and samples were removed at intervals for assay by the methods described below.

\section{Stains-all dye-binding assay of hyaluronidase activity}

Residual undegraded hyaluronate was measured by methods described previously. ${ }^{6,17}$ Samples were removed from assays and diluted appropriately with distilled water; $20-\mu \mathrm{l}$ samples were mixed with $180 \mu \mathrm{l}$ of Stains-all dye solution in clear 96-well microtitration trays (ICN-Flow Laboratories Ltd, Herts), followed by the addition of $100 \mu \mathrm{l}$ of distilled water. Absorbance values were recorded at $620 \mathrm{~nm}$ in a microtitration plate reader (Titertek, Multiscan MCC340; ICN-Flow) and residual intact hyaluronate was quantified by comparison of absorbance values with those of a series of standard hyaluronate concentrations from 0 to $200 \mu \mathrm{g} / \mathrm{ml}$.

\section{$N$-Acetylhexosamine assay of hyaluronidase activity}

$\mathrm{N}$-Acetylglucosamine residues at the reducing terminal of oligosaccharides released as a result of the degradation of hyaluronate were estimated by a modification of the method of Levvy and McAllan. ${ }^{18,19}$ The reagent for this assay was prepared by dissolving $10 \mathrm{~g}$ of 4 -(N,N-dimethylamino)-benzaldehyde (Sigma) in a solvent which comprised concentrated $\mathrm{HCl} 11 \mathrm{ml}$, water $1.5 \mathrm{ml}$ and glacial acetic acid $87.5 \mathrm{ml}$. Immediately before use, $10 \mathrm{ml}$ of this reagent was diluted to $100 \mathrm{ml}$ with glacial acetic acid (DMAB reagent). Samples $(125 \mu \mathrm{l})$ were removed from assays, added to $25 \mu \mathrm{l}$ of $0.2 \mathrm{M}$ potassium borate buffer (pH 9.0) and heated at $100^{\circ} \mathrm{C}$ for $3 \mathrm{~min}$. DMAB reagent $(750 \mu \mathrm{l})$ was added and reaction mixtures were incubated at $37^{\circ} \mathrm{C}$ for $20 \mathrm{~min} ; 200-\mu 1$ samples were dispensed into 96-well microtitration trays and absorbance values were recorded at $540 \mathrm{~nm}$ in a platereading spectrophotometer. Concentrations of $\mathrm{N}$ acetylglucosamine were determined by comparison of absorbance values with those of free $\mathrm{N}$-acetylglucosamine $(0-2 \mathrm{~mm})$ treated in the same manner.

\section{Measurement of unsaturated bond formation as a result of hyaluronidase activity}

The products of hyaluronate degradation containing carbon-carbon unsaturated bonds were determined by a modification of the method originally described by Saito et al.$^{20}$ Briefly, $75 \mu 1$ of reaction mixture were removed from assays, heated at $100^{\circ} \mathrm{C}$ for $3 \mathrm{~min}$ and cooled to room temperature. A $60-\mu 1$ sample was added to $10 \mu \mathrm{l}$ of enriched Tris buffer ${ }^{20}$ and incubated at $37^{\circ} \mathrm{C}$ for $30 \mathrm{~min} ; 0.93 \mathrm{ml}$ of $0.01 \mathrm{M} \mathrm{HCl}$ was added and absorbance values were recorded at $232 \mathrm{~nm}$ in a variable wavelength spectrophotometer (Shimadzu UV 160-A).

\section{Proton NMR measurements on the degradation products of hyaluronic acid}

Samples containing $0.5 \mathrm{ml}$ of hyaluronic acid $10 \mathrm{mg} / \mathrm{ml}$ solution, $0.35 \mathrm{ml}$ of $0.2 \mathrm{M}$ sodium phosphate 
buffer ( $\mathrm{pH} 6.0$ or 7.0 ) and $0.15 \mathrm{ml}$ of crude hyaluronidase were set up in microfuge tubes and incubated at $37^{\circ} \mathrm{C}$. All incubations were continued until at least $50 \%$ of the hyaluronate had been degraded; substrate degradation was monitored by the Stains-all dyebinding assay. Control samples contained crude hyaluronidase preparation which had been inactivated by heating at $100^{\circ} \mathrm{C}$ for $3 \mathrm{~min}$. Samples were stored at $-20^{\circ} \mathrm{C}$ for a maximum duration of $18 \mathrm{~h}$ and were thawed at ambient temperature for $\left({ }^{1} \mathrm{H}\right)$ NMR analysis.

Proton $\left({ }^{1} \mathrm{H}\right)$ NMR measurements on hyaluronate solutions pre-equilibrated with $S$. intermedius hyaluronidase or control preparations were made on a Bruker AMX-400 [University of London Inter-collegiate Research Services (ULIRS), King's College (Strand Campus) Facility, University of London] operating in quadrature detection mode at an operating frequency of $400 \cdot 14 \mathrm{MHz}$ for ${ }^{1} \mathrm{H}$. All spectra were acquired at a probe temperature of $294^{\circ} \mathrm{K}$. Typically, $0.60 \mathrm{ml}$ of sample was placed in a $5-\mathrm{mm}$ diameter NMR tube and $0.07 \mathrm{ml} \mathrm{of}{ }^{2} \mathrm{H}_{2} \mathrm{O}$ was added to provide a field frequency lock. The broad resonances arising from proteins, intact hyaluronate and alternative macromolecules present in the culture supernates were suppressed by the Carr-Purcell-Meiboom-Gill (CPMG) pulse sequence $\left(90^{\circ}\left[-\tau-180^{\circ}-\tau-\right]_{128}\right), \quad \tau=$ $1 \mathrm{~ms} .{ }^{21}$ The intense water signal was suppressed by presaturation with gated decoupling during the delay between pulses.

Single-pulse (1D) spectra of aqueous $0.5 \mathrm{mg} / \mathrm{ml}$ solutions of $\triangle$ UA GlcNAc (Dextra Laboratories Ltd, Reading) in $0.2 \mathrm{M}$ sodium phosphate buffer ( $\mathrm{pH} 7.0$ ) containing ${ }^{2} \mathrm{H}_{2} \mathrm{O} 10 \% \mathrm{v} / \mathrm{v}$ were acquired on a Bruker AMX-600 (ULIRS, Queen Mary and Westfield College Facility, University of London) spectrometer at an operating frequency of $600.13 \mathrm{MHz}$ and a probe temperature of $298^{\circ} \mathrm{K}$. Pulsing conditions were: 128 free induction delays (FIDs), with 32768 data points, $30-40^{\circ}$ pulses and a 1.93 -s pulse repetition rate, the latter to allow full spin lattice $\left(T_{1}\right)$ relaxation of the protons in the samples investigated.

Chemical shifts of resonances in spectra were referenced to external sodium 3-trimethylsilyl [2,2,3,3${ }^{2} \mathrm{H}_{4}$ ] propionate (TSP, $\delta=0.00 \mathrm{ppm}$ ). For control and $S$. intermedius-treated culture supernate samples, the methyl group resonances of lactate $(\delta=1.330 \mathrm{ppm})$, alanine $(\delta=1.487 \mathrm{ppm})$ or valine $(\delta=1.050 \mathrm{ppm})$ served as secondary internal references.

\section{Growth of S. intermedius in semi-defined media}

Semi-defined media were prepared as described previously, ${ }^{19}$ but at double strength. Hyaluronate was prepared at a concentration of $10 \mathrm{mg} / \mathrm{ml}$ and mixed in equal proportions with the medium. Solutions were filter-sterilised, dispensed into $20-\mathrm{ml}$ volumes in sterile 30-ml screw-capped containers and inoculated with a late exponential phase culture of $S$. intermedius grown in BHI broth. Cultures were incubated at $37^{\circ} \mathrm{C}$ under anaerobic conditions. At intervals throughout the growth period, $1 \cdot 5-\mathrm{ml}$ samples of culture were removed for further analysis. Growth was measured by following the absorbance of $200-\mu 1$ volumes of culture at $620 \mathrm{~nm}$ in a microtitration plate reader. The remainder of the culture samples were centrifuged and supernates were stored at $-20^{\circ} \mathrm{C}$ to determine the concentration of undegraded hyaluronate by the Stains-all dyebinding assay and lactic acid, as described previously. ${ }^{19}$

\section{Results}

\section{Characterisation of products of hyaluronidase}

The $\mathrm{pH}$ optimum of the $S$. intermedius hyaluronidase was broad, with maximum activity detected between $\mathrm{pH} 6.0$ and 6.5 , as determined by the Stainsall dye-binding assay (data not shown). At the $\mathrm{pH}$ optimum of the enzyme, hyaluronate was rapidly depolymerised (fig. 1). This resulted in an increase in the concentration of reducing terminal $\mathrm{N}$-acetylglucosamine, indicating that lower $M_{r}$ saccharide species had been formed from the hyaluronate. The absorbance at $232 \mathrm{~nm}$ increased in parallel with the rise in material which reacted in the $\mathrm{N}$-acetylglucosamine assay. Data from these chemical assays demonstrated that the hyaluronidase acted to release oligosaccharides with unsaturated carbon-carbon bonds.

Proton NMR studies were conducted with the products of the $S$. intermedius hyaluronidase activity to elucidate further their precise molecular nature. Typical $400-\mathrm{MHz}{ }^{1} \mathrm{H}-\mathrm{NMR}$ spectra of control and $S$. intermedius-treated hyaluronate (equilibrated at $\mathrm{pH} 6.0$ and 7.0) acquired with the CPMG pulse sequence are shown in fig. 2. Spectra of the control (untreated) samples contain many signals assignable to a wide variety of low- $\mathrm{M}_{\mathrm{r}}$ metabolites present in bacterial culture supernates, and illustrate the facile multicomponent analytical ability of the technique. Indeed, well resolved, sharp resonances attributable to media components and bacterial metabolites include the methyl group protons of isoleucine, valine, ethanol, lactate, alanine, acetate and acetone and the methylene groups of glutamate, glutamine, lysine and succinate are present in the high-field (aliphatic) region of these spectra, and those assignable to formate, the aromatic ring protons of tyrosine and phenylalanine, and the imidazole ring protons of histidine are readily detectable in the low-field (aromatic) region. Further features of these spectra include signals arising from the polar ${ }^{+} \mathrm{N}\left(\mathrm{CH}_{3}\right)_{3}$ head group of choline, the $\mathrm{H} 4, \mathrm{H} 6$ and $\mathrm{H} 2$ protons of myoinositol, the - $\mathrm{CH}$ group proton of lactate and the $\alpha-\mathrm{CH}$ group protons of aliphatic amino acids such as glycine, isoleucine, leucine, valine, glutamate and glutamine $(3.50-3.85 \mathrm{ppm})$ and aromatic amino acids such as phenylalanine and tyrosine (c. $4.0 \mathrm{ppm})$.

Equilibration of hyaluronate with a crude preparation of $S$. intermedius hyaluronidase at $\mathrm{pH} 6.0$ or 


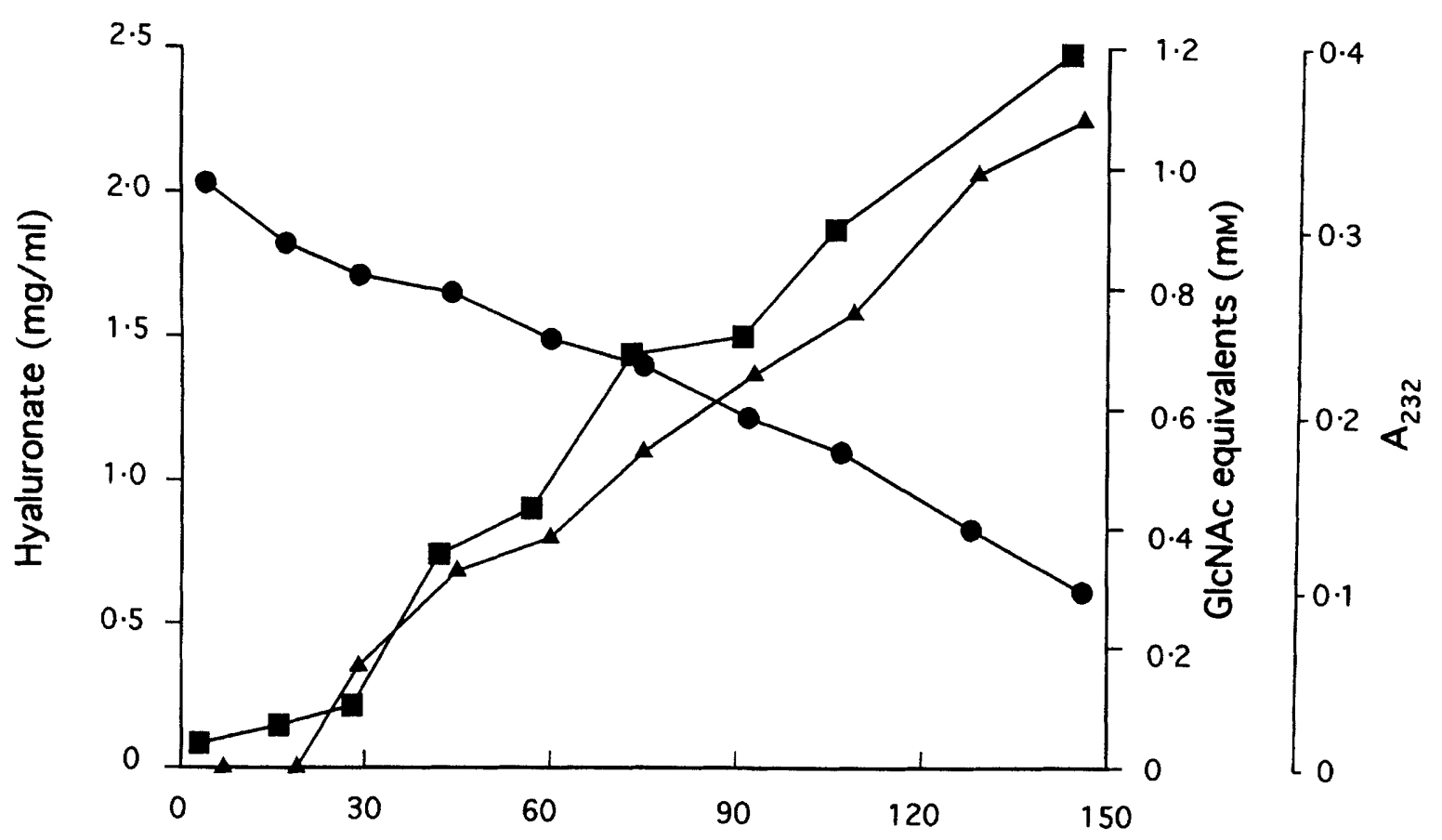

Time (min)

Fig. 1. Degradation of hyaluronate by $S$. intermedius hyaluronidase. Intact hyaluronate was measured by the Stains-all dye-binding assay ( $)$, released oligosaccharides by measuring reducing terminal $\mathrm{N}$-acetylglucosamine $(\boldsymbol{\square})$ and unsaturated carbon-carbon bonds in products by measuring the absorbance at $232 \mathrm{~nm}(\bullet)$.

$7 \cdot 0$ generated a variety of new signals in ${ }^{1} \mathrm{H}$ spectra (fig. $2 b$ and $d$ )-intense acetamido methyl group $\left(-\mathrm{NHCOCH}_{3}\right)$ singlet resonances located at 2.03 and $2.07 \mathrm{ppm}$, a complex series of sugar ring proton multiplets located in the $3.5-4.2 \mathrm{ppm}$ region, and clear doublets centred at $5 \cdot 16$ and $5.87 \mathrm{ppm}$. A further doublet of relatively weak intensity located at $5.20 \mathrm{ppm}$ was also detectable in ${ }^{1} \mathrm{H}$ spectra of hyaluronate samples pre-equilibrated with $S$. intermedius hyaluronidase. Clearly, these new signals are absent from corresponding spectra of samples containing the heat-denatured hyaluronidase preparation, confirming that the low- $\mathrm{M}_{\mathrm{r}}$ saccharides arise from the degradation of hyaluronate. Moreover, the doublet resonance located at $5.87 \mathrm{ppm}$ is characteristic of the 4-position olefinic proton of the glucuronosyl residue present in $\Delta 4,5$-unsaturated hyaluronate-derived oligosaccharides. The coupling constant for the $5.87 \mathrm{ppm}$ 4-position olefinic proton resonance present in spectra of $S$. intermedius hyaluronidase-treated hyaluronate solutions $(j=3.7 \mathrm{~Hz})$ was very similar to that of the authentic $\triangle$ UA GlcNAc sample $(j=3.9 \mathrm{~Hz})$, providing further evidence for its identity. The results obtained were completely reproducible in a total of five samples each of $S$. intermedius hyaluronidase-treated hyaluronate and those containing the heat-denatured enzyme (controls) at both pH 6.0 and 7.0 .

Further evidence for the assignment of these signals to unsaturated hyaluronate oligosaccharide species was provided by comparisons of spectra acquired on $S$. intermedius hyaluronidase-treated hyaluronate samples with an aqueous solution containing a commercially available sample of $\triangle \mathrm{UA}$ GlcNAc. Fig. 3 shows the expanded $1 \cdot 80-6.00 \mathrm{ppm}$ regions of the spectra shown in fig. 2c and d (a and b, respectively), together with the corresponding region of an aqueous solution of $\triangle U A$ GlcNAc $0.5 \mathrm{mg} / \mathrm{ml}$ in $0.2 \mathrm{M}$ sodium phosphate buffer, $\mathrm{pH} 7 \cdot 0$. A series of the new resonances generated was assignable to this unsaturated disaccharide, i.e. acetamido- $\mathrm{CH}_{3}$ group singlet located at $2.03 \mathrm{ppm}$, carbohydrate ring proton multiplets in the $3.5-4 \cdot 2 \mathrm{ppm}$ chemical shift region, and doublets at 5.16 and $5.87 \mathrm{ppm}$. The authentic sample of $\triangle U A$ GlcNAc used in these investigations consists of two anomeric forms at the GlcNAc residue (i.e. $\alpha$ - and $\beta$-) which are in an approximate ratio of $3: 2 \alpha: \beta$ in aqueous solution (C. Lawson, Dextra Laboratories Ltd, personal communication), and hence its ${ }^{1} \mathrm{H}$ spectrum contains signals arising from both anomers (e.g. $\alpha$ - and $\beta$-GlcNAc H-1 doublet resonances located at $5 \cdot 22$ and $5 \cdot 16 \mathrm{ppm}$, respectively). Indeed, some chemical shift heterogeneity in the acetamido- $\mathrm{CH}_{3}$ group signals that can be ascribed to the presence of two anomers is also apparent from its spectrum (fig. 3c). However, the ${ }^{1} \mathrm{H}$ spectra shown in fig. 1 indicate that only one anomeric form $(\beta$-) is generated from the $S$. intermedius hyaluronidasemediated depolymerisation of hyaluronate. The complete and expanded 1.9-2.3, 3.4 4.3, 5.0-5.9 and $7 \cdot 3-8.6 \mathrm{ppm}$ regions of the $600 \mathrm{MHz}{ }^{1} \mathrm{H}$ NMR spectrum of $\triangle U A$ GlcNAc are shown in fig. 4 . Further notable features of this spectrum include the broad acetamido- $\mathrm{NHCOCH}_{3}$ group signal located at 


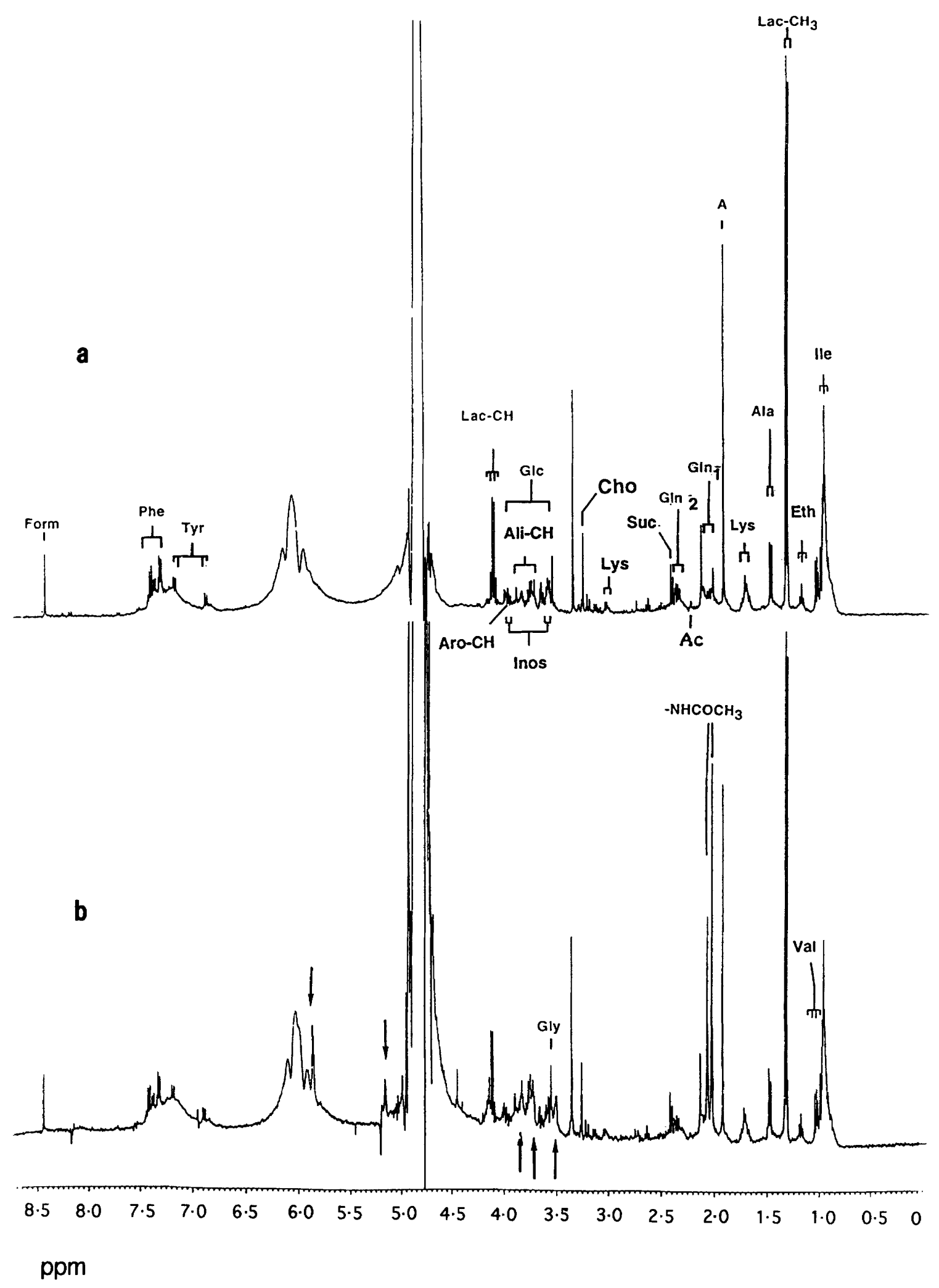

Fig. 2. $\mathbf{a}$ and $\mathbf{b}$. For legend see facing page.

$8.17 \mathrm{ppm}$, and singlet resonances arising from low levels of impurities present such as acetone and formate.

Further carbohydrate ring proton resonances located in the $3.5-4.2 \mathrm{ppm}$ chemical shift range, and the acetamido- $\mathrm{CH}_{3}$ group signal at $2.07 \mathrm{ppm}$ probably arise from higher hyaluronate-derived oligosacchar- ide species, e.g., tetra-, hexa- and octa-saccharides. Since only one olefinic glucuronosyl proton resonance $(\delta=5.87 \mathrm{ppm})$ was detected in spectra of hyaluronate samples treated with $S$. intermedius hyaluronidase, the additional signals generated appear to arise from saturated oligosaccharide species. As expected, reproducibly higher levels of $\triangle \mathrm{UA}$ GlcNAc were formed in 


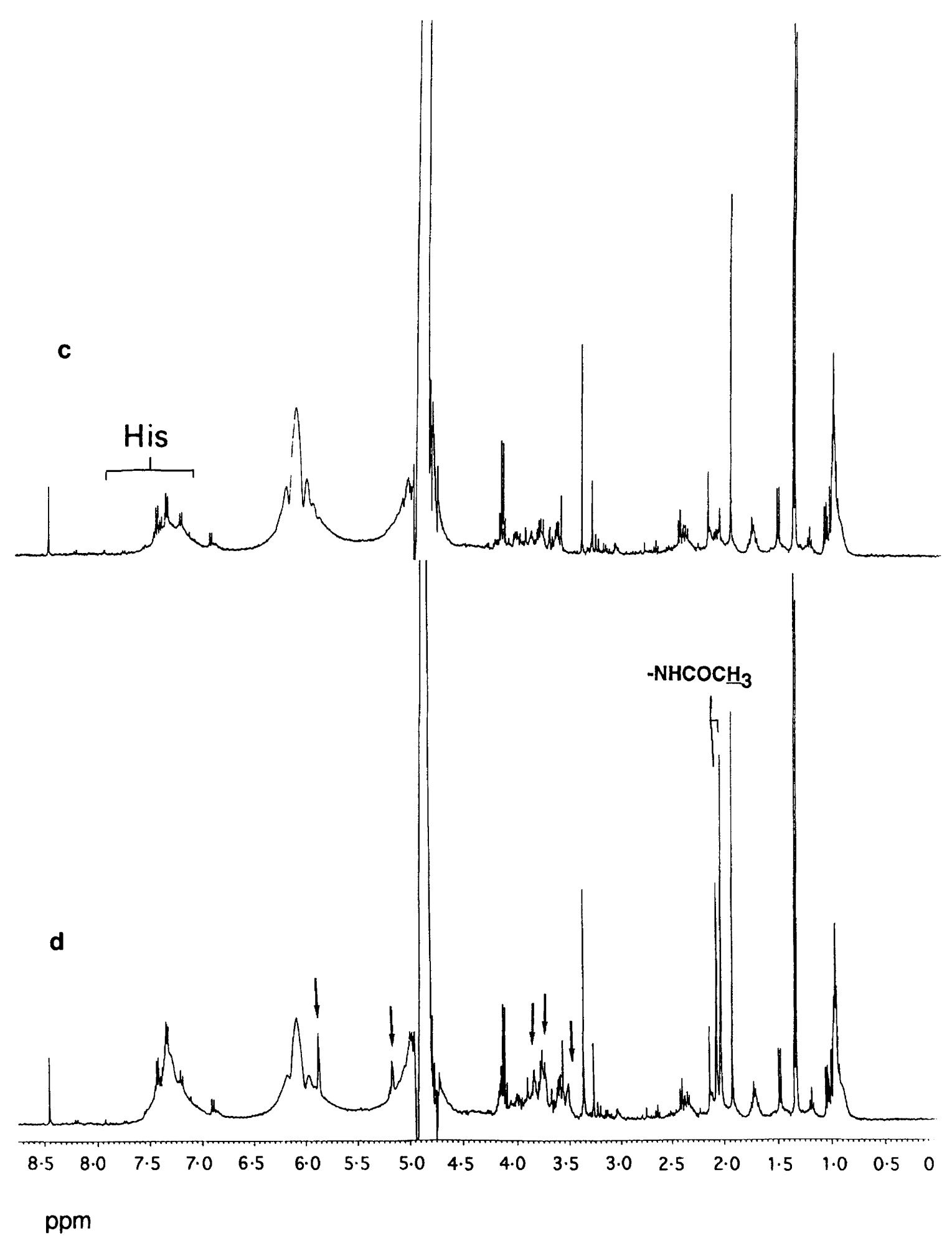

Fig. 2. Typical $400 \mathrm{MHz}{ }^{1} \mathrm{H}$ NMR spectra of supernates obtained from (a) control and (b) S. intermedius hyaluronidase-treated solutions of hyaluronate $(10 \mathrm{mg} / \mathrm{ml})$ prepared as described in Materials and methods at $\mathrm{pH} 6.0$. Corresponding spectra of supernates derived from control and hyaluronidase-treated hyaluronate solutions equilibrated at $\mathrm{pH} 7.0$ are shown in $\mathbf{c}$ and d, respectively. A, acetate- $\mathrm{CH}_{3} ; \mathrm{Ac}$, acetone- $\mathrm{CH}_{3}$ : Ala, alanine- $\mathrm{CH}_{3}$; Cho, choline- ${ }^{+} \mathrm{N}\left(\mathrm{CH}_{3}\right)_{3}$; Eth, ethanol- $\mathrm{CH}_{3}$; Form, formate-H; Gln and $\mathrm{Gln}_{2}$, $\beta$ - and $\tau$ - $\mathrm{CH}_{2}$ groups of glutamine, respectively; Gly, glycine- $\mathrm{CH}_{2}$; His, histidine imidazole ring protons; Ile, isoleucine- $\mathrm{CH}_{3}$; Inos- $\mathrm{H} 4, \mathrm{H} 6$ and $-\mathrm{H} 2$, myoinositol- $\mathrm{H} 4, \mathrm{H} 6$ and $-\mathrm{H} 2$ protons; $\mathrm{Lac}_{-} \mathrm{CH}_{3}$ and $-\mathrm{CH}$, lactate $-\mathrm{CH}_{3}$ and $-\mathrm{CH}$, respectively; Lys, lysine side-chain- $\mathrm{CH}_{2}$ groups; Phe, phenylalanine aromatic ring protons; Suc, succinate- $\mathrm{CH}_{2}$; Tyr, tyrosine aromatic ring protons; Val, valine- $\mathrm{CH}_{3}$; Ali- and Aro-CH, aliphatic and aromatic amino acid $\alpha-$ $\mathrm{CH}$ group protons, respectively. The arrows in spectra $\mathbf{b}$ and $\mathbf{d}$ denote new signals generated after treatment with $S$. intermedius hyaluronidase, attributable to hyaluronate-derived oligosaccharide fragments [e.g. acetamido $\left(-\mathrm{NHCOCH}_{3}\right)$ methyl groups, sugar ring proton multiplets, glucuronosyl residue 4-position olefinic proton doublet (5.87 ppm) and $\beta$-GlcNAc H-1 doublet (5.16 ppm)].

the samples which were equilibrated at a $\mathrm{pH}$ value of 6.0 than those obtained at $\mathrm{pH} 7 \cdot 0$, consistent with the $\mathrm{pH}$ profile for the $S$. intermedius hyaluronidase activity.

\section{Growth of S. intermedius on hyaluronate}

After $3 \mathrm{~h}$, bacterial growth was just detectable in the hyaluronate-containing cultures but a considerable 


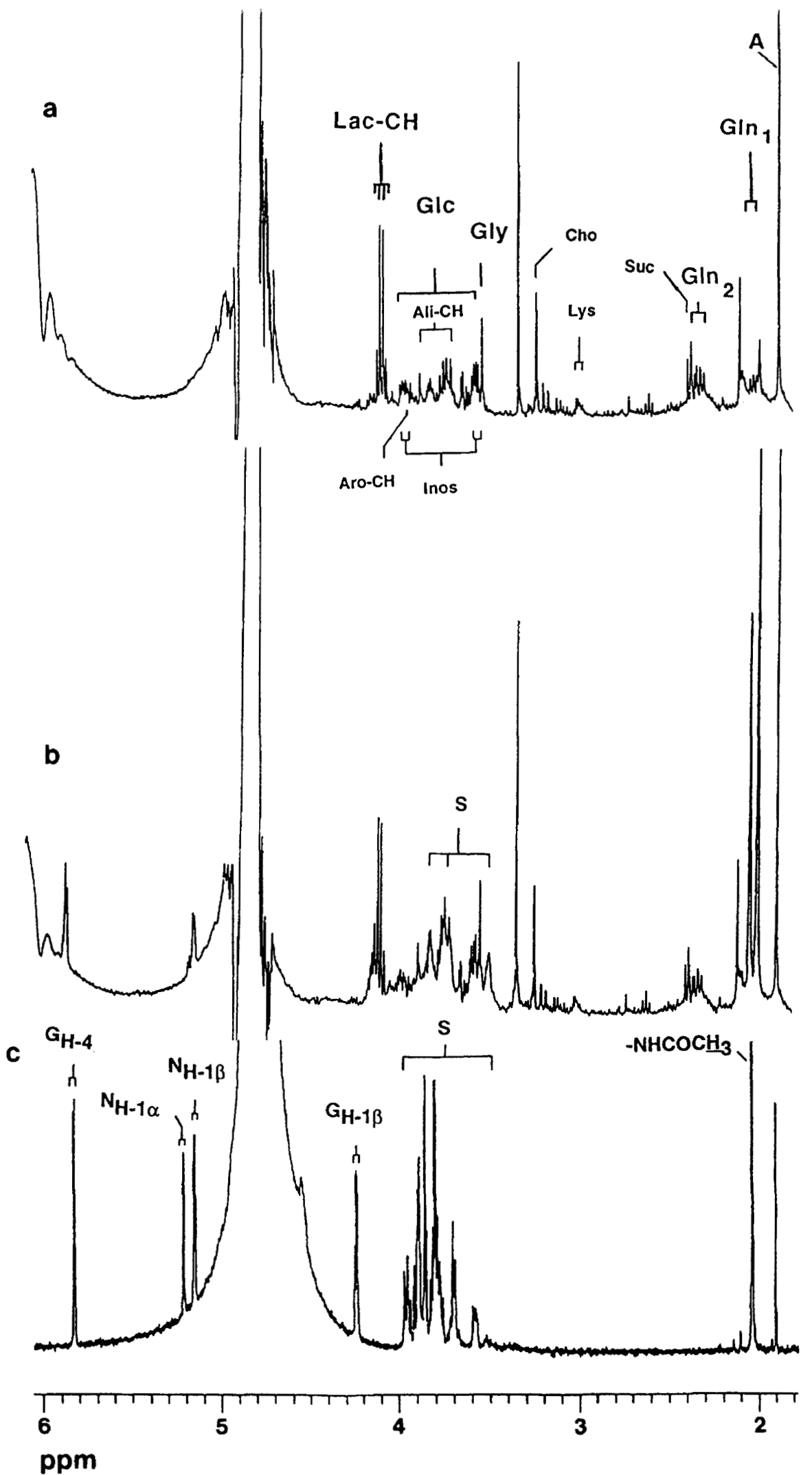

Fig. 3. a and b, Expanded 1.80-6.00 ppm regions of the spectra shown in fig. $2 \mathrm{c}$ and d, respectively. c, Corresponding region of $600 \mathrm{MHz}{ }^{1} \mathrm{H}$ NMR spectrum of an aqueous solution of the unsaturated disaccharide $\triangle U A$ GlcNAc $0.50 \mathrm{mg} / \mathrm{ml}$ in $0.2 \mathrm{M}$ phosphate buffer (pH 7.00). Abbreviations are as for fig. 1, with - $\mathrm{NHCOCH}_{3}$, acetamido methyl group; S, $\triangle \mathrm{UA}$ GlcNAc and alternative saccharide fragment sugar ring protons; $\mathrm{G}_{\mathrm{H}-1 \beta}, \mathrm{H}-1$ resonance of the $\beta$-glucuronyl anomer of $\Delta \mathrm{UA} \mathrm{GlcNAc} ; \mathrm{N}_{\mathrm{H}-1 \alpha}$ and $\mathrm{N}_{\mathrm{H}-1 \beta}, \mathrm{H}-1$ resonances of the $\alpha$ - and $\beta$-hexosaminyl anomers, respectively, of $\triangle \mathrm{UA} \mathrm{GlcNAc} ; \mathrm{G}_{\mathrm{H}-4}, 4$-position olefinic proton resonance of the glucuronyl residue present in $\triangle U A \mathrm{UlcNAc}$.

proportion of the hyaluronate was depolymerised (table). After $5 \mathrm{~h}$ no intact hyaluronate was present and the absorbance of cultures and supernate lactate concentration had started to increase. At the end of the exponential phase of growth $(17 \mathrm{~h})$ there was a significant increase in absorbance and the lactate 

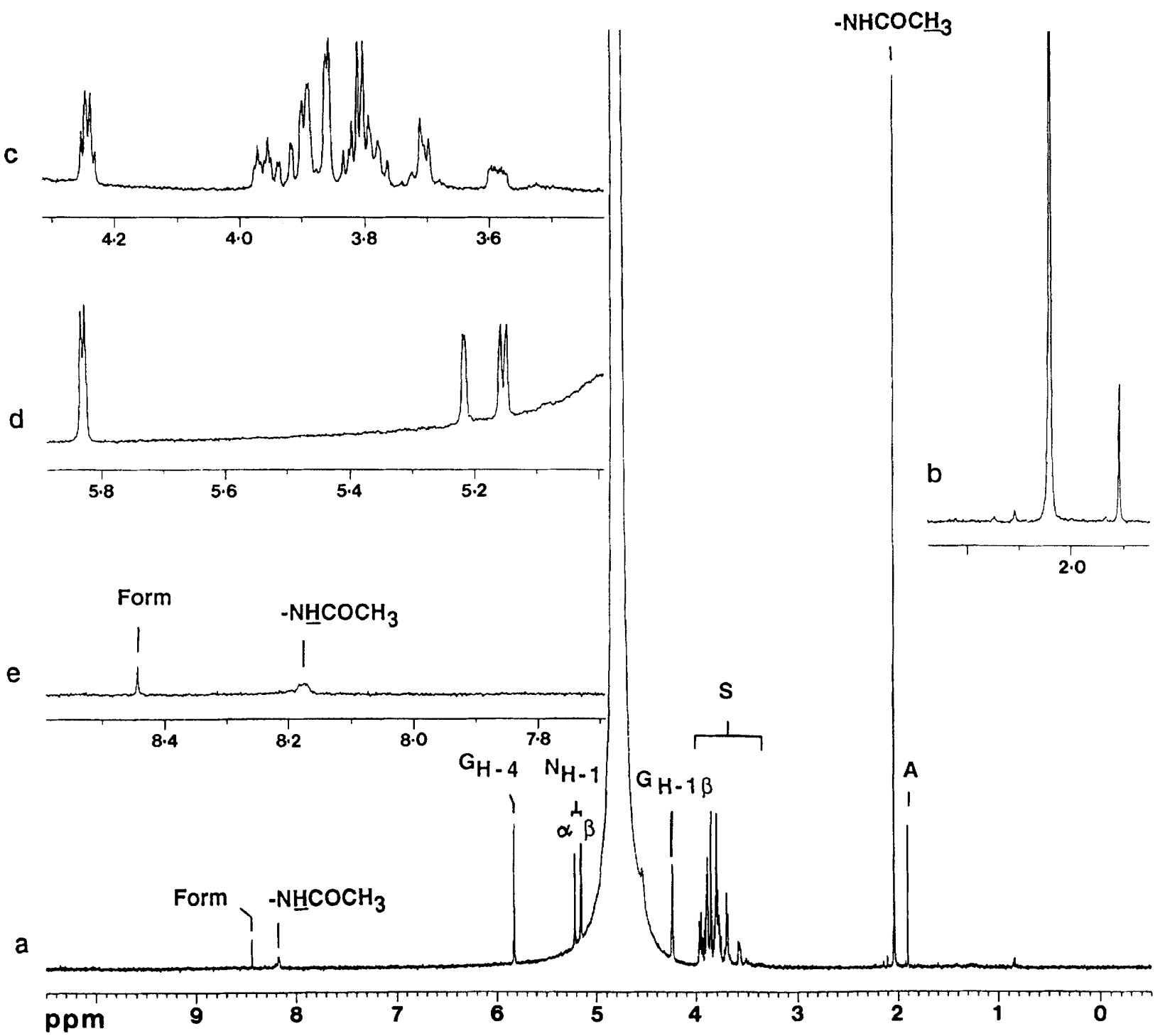

Fig. 4. a, Complete and expanded 1.9-2.3 (b), 3.4-4.3 (c), 5.0-5.9 (d) and 7.3-8.6 (e) ppm regions of the 600-MHz ${ }^{1} \mathrm{H}-\mathrm{NMR}$ spectrum of $\Delta \mathrm{UA}$ GlcNAc. Abbreviations as in figs 2 and 3, with $-\mathrm{NHCOCH}_{3}$ representing the acetamido amide group proton resonance.

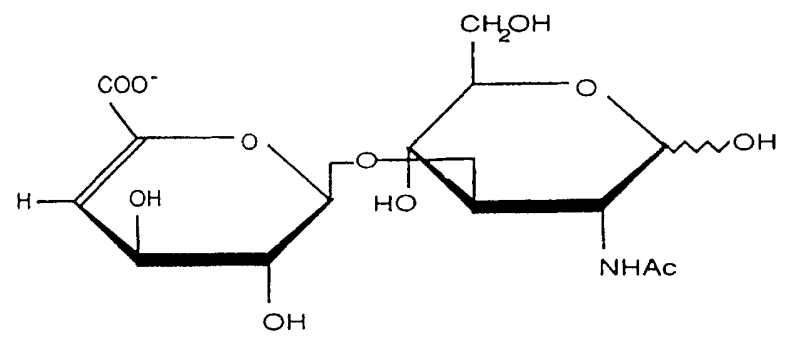

Fig. 5. $\triangle \mathrm{UA}$ GlcNAc, the major product of the $S$. intermedius hyaluronidase.

Table. Growth of $S$. intermedius on hyaluronate in minimal medium

\begin{tabular}{rccc}
\hline Time (h) & $\begin{array}{c}\text { Rncrease } \\
\text { in } \mathrm{A}_{620}\end{array}$ & $\begin{array}{c}\text { Residual } \\
\text { hyaluronate } \\
\text { concentration } \\
(\mathrm{mg} / \mathrm{ml})\end{array}$ & $\begin{array}{c}\text { Lactate } \\
\text { concentration } \\
(\mathrm{mM})\end{array}$ \\
\hline 0 & 0.000 & 5.0 & 0.91 \\
3 & 0.013 & 1.2 & 1.49 \\
5 & 0.120 & $<0.2$ & 1.53 \\
17 & 0.324 & $<0.2$ & 5.78 \\
\hline
\end{tabular}

concentration had reached $5.78 \mathrm{~mm}$ indicating that hyaluronic acid had been metabolised as a source of nutrient. No growth was observed in minimal medium in the absence of carbohydrate (data not shown).

\section{Discussion}

The multicomponent ability of high-field NMR spectroscopy facilitated the detection and determination of the relative abundance of specific oligosaccharide species arising from the cleavage of hyaluronate by the hyaluronidase of $S$. intermedius. We have shown unambiguously that the major product is the hyaluronate disaccharide unsaturated in the 4,5-position of the glucuronosyl residue ( $\Delta \mathrm{UA}$ GlcNAc; fig. 5). The formation of unsaturated products is a characteristic of virtually all bacterial hyaluronidases $;^{5,8,22}$ this distinguishes them from the mammalian enzymes which give rise to saturated oligosaccharides. $\left({ }^{1} \mathrm{H}\right) \mathrm{NMR}$ analysis of extracts of liver or brain abscess aspirates could provide much 
useful diagnostic information regarding the nature and prevalence of hyaluronidase-producing species, including $S$. intermedius. The olefinic $-\mathrm{CH}$ group resonance $(5.87 \mathrm{ppm}$ for $\triangle \mathrm{UA}$ GlcNAc) characteristic of such catabolites located in a spectral region uncluttered by signals from endogenous metabolites would facilitate their detection.

The production of hyaluronidase by the "S. milleri" group of organisms has long been recognised as a putative virulence determinant. ${ }^{3,4,23,24}$ The enzyme is assumed to play a role in the destruction of host connective tissue and in facilitating the spread of the organism, and others associated with polymicrobial abscesses, through tissue planes at the site of the infection. ${ }^{23,24}$ However, tissue breakdown alone is insufficient to allow the formation of these purulent abscesses; bacteria must be capable of obtaining a source of nutrient in order to replicate. ${ }^{25} S$. intermedius utilised hyaluronate as its sole source of fermentable carbohydrate. Thus hyaluronidase degraded hyaluronate yielding primarily an unsaturated disaccharide, utilised as a source of nutrient with the formation of lactate. Therefore, we suggest that the $S$. intermedius hyaluronidase may play a role not only in the destruction of host tissue but also in bacterial nutrition.

M.C.G. and D.P.N are grateful to the Arthritis and Rheumatism Research Council (UK) for financial support and we acknowledge the University of London Intercollegiate Research Services for the provision of NMR facilities.

\section{References}

1. Laurent TC. Biochemistry of hyaluronan. Acta Otolaryngol (Stockh) Suppl 1987; 442: 7-24.

2. Kjellen L, Lindahl U. Proteoglycans: structures and interactions. Annu Rev Biochem 1991; 60: 443-475.

3. Unsworth PF. Hyaluronidase production in Streptococcus milleri in relation to infection. $J$ Clin Pathol 1989; 42: $506-510$.

4. Ruoff KL, Ferraro MJ. Hydrolytic enzymes of " Streptococcus milleri". J Clin Microbiol 1987; 25: 1645-1647.

5. Tam Y-C, Chan ECS. Purification and characterization of hyaluronidase from oral Peptostreptococcus species. Infect Immun 1985; 47: 508-513.

6. Homer KA, Denbow L, Whiley RA, Beighton D. Chondroitin sulfate depolymerase and hyaluronidase activities of viridans streptococci determined by a sensitive spectrophotometric assay. J Clin Microbiol 1993; 31 : 1648-1651.

7. Whiley RA, Beighton D, Winstanley TG, Fraser HY, Hardie JM. Streptococcus intermedius, Streptococcus constellatus, and Streptococcus anginosus (the Streptococcus miller group): association with different body sites and clinical infections. $J$ Clin Microbiol 1992 ; 30: 243-244.

8. Hamai A, Morikawa K, Horie K, Tokuyasu K. Purification and characterization of hyaluronidase from Streptococcus dysgalactiae. Agric Biol Chem 1989; 53: 2163-2168.

9. Hill J. Purification and properties of streptococcal hyaluronate lyase. Infect Immun 1976; 14: 726-735.

10. Linker A, Meyer K, Hoffman P. The production of unsaturated uronides by bacterial hyaluronidases. $J$ Biol Chem 1956 ; 219: 13-25.

11. Nicholson JK, Buckingham MJ, Sadler PJ. High resolution ${ }^{1} \mathrm{H}$ n.m.r. studies of vertebrate blood plasma. Biochem $J 1983$; 211: 605-615

12. Grootveld M, Claxson AWD, Chander CL, Haycock P, Blake DR, Hawkes GE. High resolution proton NMR investigations of rat blood plasma. Assignment of resonances for the molecularly mobile carbohydrate sidechains of 'acute-phase' glycoproteins. FEBS Lett 1993; 322: $266-276$.

13. Naughton DP, Haywood R, Blake DR, Edmonds S, Hawkes GE, Grootveld $M$. A comparative evaluation of the

metabolic profiles of normal and inflammatory knee-join synovial fluids by high resolution proton NMR spectroscopy. FEBS Lett 1993; 332: 221-225.

14. Stevens CR, Bucurenci N, Abbot SE et al Application of methionine as a detector molecule for the assessment of oxygen radical generation by human neutrophils and endothelial cells. Free Rad Res Commun 1992; 17: 143-154.

15. Hahn EL. Physiol Rev 1950; 80: 580 .

16. Farrar TC, Becker ED. Pulse and Fourier Transform NMR. Introduction to theory and methods. New York, Academic Press, 1971.

17. Homer KA, Denbow L, Beighton D. Spectrophotometric method for the assay of glycosaminoglycans and glycosaminoglycan-depolymerizing enzymes. Ann Biochem 1993; 214 : 435-441.

18. Levvy GA, McAllan A. The N-acetylation and estimation of hexosamines. Biochem $J$ 1959; 73: 127-132.

19. Homer K, Patel R, Beighton D. Effects of N-acetylglucosamine on carbohydrate fermentation by Streptococcus mutans NCTC 10449 and Streptococcus sobrinus SL-1. Infect Immun 1993; 61: 295-302.

20. Saito H, Yamagata T, Suzuki S. Enzymatic methods for the determination of small quantities of isomeric chondroitin sulphates. $J$ Biol Chem $1968 ; 243$ : 1536-1542.

21. Sanders JKM, Hunter BK. Modern NMR spectroscopy. A guide for chemists. Oxford, Oxford University Press, 1987 250-251.

22. Tippler LS, Embery G. Glycosaminoglycan-depolymerizing enzymes produced by anaerobic bacteria isolated from the human mouth. Arch Oral Biol 1985; 30: 391-396.

23. Ruoff KL. Streptococcus anginosus ("Streptococcus milleri"): the unrecognized pathogen. Clin Microbiol Rev 1988; 1 102-108.

24. Piscitelli SC, Shwed J, Schreckenberger P, Danziger LH Streptococcus milleri group: renewed interest in an elusive pathogen. Eur $J$ Clin Microbiol Infect Dis 1992; 11 491-498.

25. Reid G, Bruce AW, McGroarty JA, Cheng KJ, Costerton JW Is there a role for lactobacilli in prevention of urogenital and intestinal infections? Clin Microbiol Rev 1990; 3 . 335-344. 